\title{
PENINGKATAN PENJUALAN MELALUI EKSEBISI DAN SERTIFIKASI HALAL
}

\author{
Oleh: \\ Taufik Alwi ${ }^{1}$, Sunarso ${ }^{2}$, R. Titin Maidarti ${ }^{3}$ \\ Sekolah Tinggi Ilmu Ekonomi IPWI Jakarta \\ Email: alwitaufik@yahoo.com ${ }^{2}$, sunarso.ipwija@yahoo.com ${ }^{1)}$
}

\begin{abstract}
ABSTRAK
Penelitian ini bertujuan untuk mengetahui dan menganalisis pengaruh Eksebisi dan Sertifikasi Halal terhadap Penjualan. Metode penelitian berupa metode Survey dengan instrument penelitian berupa kuesioner dalam pertanyaan tertutup dengan 5 alternatif jawaban berdasarkan 5 Skala Likert. Sampel penelitian ditentukan denganteknik sampling dengan purposive non probability sampling dimana jumlah sampel penelitian sebanyak 55 Stan (boots pameran).

Metode analisis secara kuantitatif melalui statistic inferensial untuk mengetahui pengaruh variabel yang diteliti. Disimpulkan bahwa Eksebisi berpengaruh signifikan dalam arah yang positif terhadap penjualan produk halal. Demikian pula, sertifikasi halal berpengaruh signifikan dalam arah yang positif terhadap peningkatan penjualan produk halal.
\end{abstract}

Kata kunci:

Penjualan Produk, Sertifikasi Halal, Promosi, Eksebisi

Submit: 30 April 2019

Review: 30 April 2019

Publish: 30 April 2019

\section{PENDAHULUAN}

Potensi populasi Muslim sebagai pasar produk halal diperkirakan akan tumbuh lebih dari USD 58,3 miliar pada tahun 2022. Sektor terbesar industri halal global adalah keuangan syariah dengan market share 43 persen, diikuti oleh makanan halal dengan pangsa pasar 36 persen sebagaimana laporan Global Halal Market (2018). Indonesia sebagai Negara berpenduduk muslim terbesar di dunia sangat berpotensi memimpin halal industry secara global. Halal tidak hanya berlaku untuk produksi makanan dan minuman (food and beverages) namun telah berevolusi menjadi konsep halal holistic yang mencakup seluruh nilai kegiatan komersial. Pasar halal tidak eksklusif untuk umat Islam, dan secara inklusif telah mendapatkan peningkatan penerimaan di kalangan konsumen nonMuslim yang mengaitkan halal dengan etika konsumerisme.

Pameran (exhibition) sebagai media publisitas sekaligus bagian dari industri MICE (Meeting, Incentive, Confference and Exhibition) secara dinamis mengalami peningkatan pada skala nasional, regional bahkan internasional. Partisipasi 
perusahaan melalui kegiatan pameran produk merupakan salah satu strategi promosi yang digunakan untuk meningkatkan penjualan produk. Penyelenggara pameran menyesuaikan target peserta sesuai dengan industri terkait. Salah satunya adalah pameran produk halal (skala nasional dan bahkan internasional) diselenggarakan oleh Lembaga Pengkajian Pangan, Obat-obatan, dan Kosmetika Majelis Ulama Indonesia (LPPOM MUI) melalui kegiatan Expo produk Halal yang secara rutin setiap tahun diselenggarakan sejak tahun 2011.

UMKM yang inovatif dalam menghasilkan produk halal tertantang untuk meningkatkan jangkauan pasar baik nasional maupun internasional salah satunya dengan mengikuti kegiatan Expo produk halal sekaligus sebagai media mengembangkan eksistensi usaha, disampingkan pengembangan platform digital melalui pemanfaat e-commerce dan media social. Pameran berguna untuk memperkenalkan produk, memperluas jaringan (networking), akses investor, perbaikan kualitas produk, memperoleh informasi persaingan, memperkuat image perusahaan, survei pasar dan meningkatkan penjualan.

Kendala sertifikasi produk halal (Prabowo, 2014) diantaranya kurangnya sosialisasi dan informasi telah menyebabkan kurangnya pengetahuan dan kesadaran pelaku usaha. Bagi pengusaha yan mengetahui adanya prospek dari halal hub, cenderung mengurus sertifikasi halal (Abdul, et al., 2012).

Fokus masalah dalam penelitian ini bagaimana pengaruh kegiatan pameran dan sertifikasi dalam peningkatan penjualan.

\section{TUJUAN PENELITIAN}

Penelitian ini bertujuan untuk mengetahui dan menganalisis pengaruh Eksebisi dan Sertifikasi Halal terhadap Penjualan.

\section{TELAAH LITERATUR DAN PENGEMBANGAN HIPOTESIS Sertifikasi Halal}

Halal adalah istilah Arab yang berarti "diizinkan" (permissible) sebaliknya haram (impermissible) dan mengacu pada seperangkat aturan dalam Islam yang menentukan kegiatan yang diizinkan dan dilarang dalam menggunakan suatu produk. Muatasim Ismaeel (2012) menjelaskan bahwa Islam mengizinkan dan menerima berbagai tingkat komitmen etis, salah satunya esensi etika dan pendekatan penerapan sertifikasi halal. Terdapat dua perkembangan penting yang bisa memperkaya praktik bisnis halal yaitu harmonisasi standar global (global standards) dan struktur tata kelola, dan integrasi tanggung jawab dan etika dalam standar halal (halal standards).

Undang-Undang Jaminan Produk Halal (UUJPH) bertujuan memberikan kenyamanan, keamanan, keselamatan, dan kepastian ketersediaan produk halal bagi masyarakat dalam mengonsumsi dan menggunakan produk sehingga masyarakatkan mendapatkan ketenangan batin dalam mengkonsumsi dan menggunakan barang.

Marzuki, Hall dan Ballentine (2012) dengan metode wawancara 30 pengelola restoran diketahui bahwa sertifikasi halal penting memenuhi syarat diet konsumen Muslim. Awan, Siddiquei dan Haider (2014) melalui penelitian dengan metode survey pada 300 responden diketahui bahwa sertifikasi halal merupakan hal penting yang dipertimbangkan konsumen 
Muslim yang tentunya mempengaruhi penjualan.

\section{Pameran (Exhibition)}

Beragam bentuk pameran seperti: bazaar, expo, fair, pekan raya, pasar murah dan show. Pameran merupakan salah satu kegiatan yang digunakan untuk memperkenalkan produk yang dihasilkan perusahaan dan pedagang sekaligus bagian untuk mempertinggi volume penjualan perusahaan.

Studi Hung, Ching dan Chi (2016) mengkonseptualisasikan layanan pameran melalui validasi penggunaan empat dimensi primer yaitu: kualitas interaksi, kualitas fisik lingkungan, kualitas hasil, dan kualitas akses.

Dalam kegiatan pameran, terdapat 3 bentuk interaksi antara peserta pameran dan pengunjung pameran/konsumen yang dapat dievaluasi pada tiga fase yaitu: promosi pra-pameran, penjualan saat pameran, dan tindak lanjut pasca-pameran (Li, 2008). Peserta pameran (Exhibitors) menggunakan beberapa cara untuk menarik pengunjung untuk mengunjungi stan (booths) mereka. Selama promosi prapertunjukan, peserta pameran menggunakan insentif yang efektif, seperti sovenir, atau hadiah, untuk menarik peserta untuk mengunjungi stan. Selama promosi di pameran, peserta pameran berkompetisi melalui ukuran stan, lokasi, desain, teknik yang menarik perhatian, dan tampilan dan inovasi produk. Pada tahapan pasca-pameran, staf stan menganalisis dan menindaklanjuti respon pengunjung dalam prospek pembelian di masa depan untuk mencapai tujuan penjualan (Lin, 2013).

Sonang Sitohang (2008) pameran perdagangan (trade exhibition) secara signifikan mempengaruhi kinerja pemasaran. Emi Supariyani (2004) bahwa biaya promosi melalui pameran yang telah dikeluarkan

perusahaan dapat meningkatkan volume penjualan.

Joko Mei Rianto dan Meizy Heriyanto (2015) Pameran berpengaruh secara signifikan terhadap tingkat Penjualan, karena dengan Pameran yang tepat, baik dan terarah dapat meningkatkan penjualan.

Anna Wulandari dan M. Echsanullah (2018) menemukan bahwa Pameran memiliki pengaruh terhadap Penjualan dengan arah positif, artinya semakin tinggi Pameran maka semakin tinggi pula Penjualan.

Daroin (2015) menjelaskan bahwa keikutsertaan dalam kegiatan pameran dapat meningkatkan kinerja pemasaran perusahaan.

Penyelenggaraan

pameran merupakan salah satu cara yang sangat praktis bagi perusahaan untuk memperkenalkan produknya kepada pembeli (customer) baik di lingkup pasar domestik maupun internasional.

\section{Sertifikasi Halal (Halal Certification)}

Chen, et al. (2015) yang meneliti 115 perusahaan di Selandia Baru yang disertifikasi oleh pihak ketiga akan mengalami peningkatan kinerja pasar dan hubungan yang lebih baik dengan pelanggan.

Penelitian Talib (2016) pada 210 perusahaan manufaktur makanan bersertifikat Halal di Malaysia dimana data dikumpulkan melalui kuesioner terstruktur dan dianalisis menggunakan teknik pemodelan persamaan struktural. Ditemukan bahwa penerapan sertifikat halal secara positif mempengaruhi kinerja bisnis. perusahaan makanan bersertifikat halal dan makanan tidak bersertifikat halal perusahaan memiliki perbedaan signifikan dalam hal kinerja inovatif dan kinerja pasar. 
Salindal (2018), penelitian melalui survei yang melibatkan 211 perusahaan makanan (141) bersertifikat halal dan 70 tidak bersertifikat halal. Hasilnya dianalisis menggunakan analisis faktor konfirmatori, pemodelan persamaan struktural dan uji-t sampel independen. Ditemukan hasil riset bahwa sertifikasi halal secara signifikan mempengaruhi kinerja inovatif perusahaan makanan bersertifikat halal. Kedua, peningkatan kinerja inovatif mengarah pada peningkatan kinerja pasar pada aspek penjualan. Demikian juga penelitian dari Karim, et.al (2018) melalui aplikasi structural equation modeling techniques (SEM) menemukan bahwa kepercayaan (trusth) pada produk makanan yang bersertifikat halal berdampak positif pada kinerja (performance) dari pabrikan makanan halal di Malaysia.

\section{Penjualan}

Penjualan berkaitan dengan upaya menjajakan produk dengan sedemikian rupa sehingga pembeli bertransaksi. Cara yang dilakukan dengan aktivitas seperti analisa pasar, pengaturan produk, inovasi, potongan harga, mengadakan pameran (Kotler dan Amstrong. 2014). Kinerja penjualan dapat diukur melalui indikator seperti volume penjualan, pertumbuhan pelanggan, serta pertumbuhan penjualan.

\section{Kerangka Penelitian}

Kerangka pengaruh Eksebisi dan sertifikasi halal terhadap penjualan dapat digambarkan sebagai berikut:

Gambar 1

Kerangka Penelitian

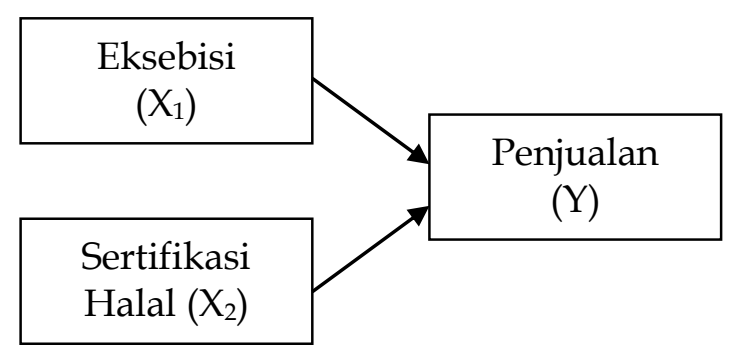

Pengaruh eksebisi terhadap penjualan ditunjukkan dalam beberapa penelitian seperti: Emi Supariyani (2004) bahwa biaya promosi melalui pameran yang telah dikeluarkan perusahaan dapat meningkatkan volume penjualan. Joko Mei Rianto dan Meizy Heriyanto (2015) Pameran berpengaruh secara signifikan terhadap tingkat Penjualan. Demikian juga penelitian Anna Wulandari dan $M$. Echsanullah (2018) menemukan bahwa Pameran memiliki pengaruh terhadap Penjualan dengan arah positif, artinya semakin tinggi Pameran maka semakin tinggi pula Penjualan.

Dari beberapa penelitian tersebut maka diduga eksebisi berpengaruh terhadap penjualan .

H1: Eksebisi berpengaruh terhadap Penjualan

Pengaruh sertifikasi halal terhadap penjualan ditunjukkan oleh penelitian Chen, et al. (2015) yang meneliti 115 perusahaan di Selandia Baru yang disertifikasi oleh pihak ketiga akan mengalami peningkatan kinerja pasar. Awan, Siddiquei dan Haider (2014) melalui penelitian dengan metode survey pada 300 responden diketahui bahwa sertifikasi halal merupakan hal penting yang dipertimbangkan konsumen Muslim yang mempengaruhi penjualan.

Dengan demikian diduga sertifikasi halal berpengaruh terhadap penjualan.

H2: Sertifikasi berpengaruh terhadap Penjualan

\section{METODE PENELITIAN Metode Penelitian}

Metode penelitian yang diterapkan adalah metode survey dengan menggunakan kuesioner berupa pertanyaan tertutup (terdapat 5 alternatif jawaban dari persepsi responden berupa 5 skala Likert) kepada responden penelitian. 
Sampel Penelitian

$$
\text { Lokasi Penelitian pada }
$$

penyelengaraan Indonesia Halal Expo 2018, pada tanggal 1-3 Desember 2018 di Smesco Jakarta. Peserta yang dijadikan sampel dibatasi pada peserta pameran yang menghasilkan produk-produk yang telah bersertifikat halal dari LPOM MUI. Teknik sampling dengan purposive non probability sampling dimana jumlah sampel penelitian sebanyak 55 Stan (boots pameran).

\section{Desain Penelitian}

Dalam penelitian terdiri dari 2 variabel bebas (independent variables) yaitu Eksebisi dan Sertifikasi halal serta 1 variabel terikat (dependent variable) yaitu penjualan.

\section{Operasionalisasi Variabel}

Operasionalisasi variabel penelitian dapat dikemukakan sebagai berikut:

\section{Tabel 1}

Operasionalisasi Variabel

\begin{tabular}{|c|c|c|}
\hline Variabel/ Sumber & Indikator & Skala \\
\hline $\begin{array}{l}\text { Eksebisi } \\
\text { (Sitohang (2008, } \\
\text { Li, 2008, Lin, 2013, } \\
\text { Hung, Ching dan } \\
\text { Chi, 2016) }\end{array}$ & $\begin{array}{l}\text { Keamanan venue } \\
\text { dan akomodasi, } \\
\text { Biaya yang bersaing, } \\
\text { Kelengkapan } \\
\text { Fasilitas, } \\
\text { Kemudahan Akses, }\end{array}$ & $\begin{array}{l}5 \text { Skala } \\
\text { Likert }\end{array}$ \\
\hline $\begin{array}{l}\text { Sertifikasi Halal, } \\
\text { (Awan, Siddiquei } \\
\text { dan Haider, 2014, } \\
\text { Karim, et.al 2018, } \\
\text { Salindal 2018), } \\
\end{array}$ & $\begin{array}{l}\text { Kemudahan } \\
\text { Pengurusan, } \\
\text { Biaya Pengurusan, } \\
\text { Masa Berlaku, } \\
\text { Diversifikasi Produk }\end{array}$ & $\begin{array}{c}5 \text { Skala } \\
\text { Likert }\end{array}$ \\
\hline $\begin{array}{l}\text { Penjualan } \\
\text { (Kotler dan } \\
\text { Amstrong. 2014). }\end{array}$ & $\begin{array}{l}\text { Akses Permintaan } \\
\text { pembeli } \\
\text { Ragam Produk yang } \\
\text { terjual, volume } \\
\text { penjualan, } \\
\text { pertumbuhan } \\
\text { pelanggan, serta } \\
\text { pertumbuhan } \\
\text { penjualan }\end{array}$ & $\begin{array}{c}5 \text { Skala } \\
\text { Likert }\end{array}$ \\
\hline
\end{tabular}

\section{Metode Analisis}

Metode analisis menggunakan uji asumsi klasik seperti uji validitas, reliabilitas dan normalitas data, uji korelasi, uji determinasi, uji t, uji F (Anova), uji persamaan regresi. Uji statistik inferensial untuk menguji hipotesis penelitian serta analisisnya.

\section{HASIL PENELITIAN DAN \\ PEMBAHASAN \\ Hasil Penelitian}

Uji Validitas dan Reliabilitas Variabel Eksebisi $\left(X_{1}\right)$

Berdasarkan hasil Pearson Correlation diperoleh $\mathrm{X}_{11}: 0745, \quad \mathrm{X}_{12}: 0874, \quad \mathrm{X}_{13}: 0,732$, $X_{14}: 0,911, \quad X_{15}: 0,872, \quad X_{16}: 0868, \quad X_{17}: 0,801$, $X_{18}: 0,762, X_{19}: 0,767$ dan $X_{110}: 0,829$ semuanya menunjukkan nilai $r_{\text {hitung }}>r_{\text {tabel. }}$. Hasil tersebut berarti bahwa seluruh butir instrumen penelitian (kuesioner) pada variabel Eksebisi $\left(\mathrm{X}_{1}\right)$ dinyatakan valid.

Menurut Sekaran (2001), reliabilitas kurang dari 0,6 adalah kurang baik, sedangkan 0,7 dapat diterima dan di atas 0,8. Uji reliabilitas Eksebisi $\left(\mathrm{X}_{1}\right)$ diperoleh nilai Cronbach's Alpha 0,937 > nilai $\mathrm{r}_{\text {tabel }}$ 0,6 sehingga dinyatakan bahwa instrumen penelitian Eksebisi $\left(\mathrm{X}_{1}\right)$ adalah Reliabel.

\section{Uji Validitas dan Reliabilitas Variabel Sertifikasi Halal $\left(\mathrm{X}_{2}\right)$}

Berdasarkan hasil Pearson Correlation diperoleh $X_{21}: 0,913, X_{22}: 0,773, \quad X_{23}: 0,789$, $X_{24}: 0,898, \quad X_{25}: 0,880, \quad X_{26}: 0,780, \quad X_{27}: 0,808$, $X_{28}: 0,779, X_{29}: 0,735$ dan $X_{210}: 0,900$ semuanya menunjukkan nilai $r_{\text {hitung }}>r_{\text {tabel. Hal }}$ tersebut berarti bahwa seluruh butir instrumen penelitian (kuesioner) pada variabel sertifikasi halal $\left(\mathrm{X}_{2}\right)$ dinyatakan valid.

Uji Reliabilitas sertifikasi halal $\left(\mathrm{X}_{2}\right)$ dengan nilai alpha $0,944>$ Nilai $r_{\text {tabel }}=0,666$ sehingga instrumen sertifikasi halal $\left(X_{2}\right)$ dinyatakan Reliabel. 
Uji Validitas dan Reliabilitas Variabel Penjualan (Y)

Berdasarkan hasil Pearson Correlation diperoleh $\quad \mathrm{Y}_{1}: 0,923, \quad \mathrm{Y}_{2}: 0,857, \quad \mathrm{Y}_{3}: 0,732$, $\mathrm{Y}_{4}: 0,845, \quad \mathrm{Y}_{5}: 0,911, \quad \mathrm{Y}_{6}: 0,888, \quad \mathrm{Y}_{7}: 0,949$, $\mathrm{Y}_{8}: 0,880, \mathrm{Y}_{9}: 0,939$ dan $\mathrm{Y}_{10}: 0,894$ semuanya menunjukkan nilai $r_{\text {hitung }}>r_{\text {tabel }}$. Hal tersebut berarti bahwa seluruh butir instrumen penelitian (kuesioner) pada variabel Penjualan $(\mathrm{Y})$ dinyatakan valid.

Uji Reliabilitas variabel Penjualan $(Y)$ dengan nilai alpha sebesar $0,948>$ nilai $r_{\text {tabel }}$ 0,666, sehingga instrumen penelitian variabel Penjualan (Y) dinyatakan Reliabel.

\section{Uji Normalitas}

Untuk mengetahui berdistribusi normal atau tidaknya data-data dari variabel independen $\left(X_{1}\right.$, dan $\left.X_{2}\right)$ maupun variabel dependen $(\mathrm{Y})$ dilakukan Uji normalitas Chi Square. Hasil uji normalitas masing-masing diperoleh nilai $X^{2}$ hitung Eksebisi $\left(X_{1}\right)$ sebesar 25,673, Sertifikasi halal $\left(X_{2}\right)$ sebesar 20109 dan Penjualan (Y) sebesar 39,927 sedangkan nilai $X^{2}$ tabel masing-masing sebesar 41,337 untuk $X_{1}$, 38,885 untuk $\mathrm{X}_{2}$ dan 42,557 untuk $\mathrm{Y}$. Semuanya menunjukkan $X^{2}{ }_{\text {hitung }}$ lebih kecil dari pada $X^{2}$ tabel. yang berarti ketiga variabel tersebut berdistribusi normal..

\section{Analisis Koefisien Korelasi Parsial}

Tabel 2

Hasil Analisis Korelasi Parsial

\begin{tabular}{|c|c|c|c|c|}
\hline \multicolumn{5}{|c|}{ Correlations } \\
\hline & & $\begin{array}{l}\text { Eksebisi } \\
\text { (X1) }\end{array}$ & $\begin{array}{l}\text { Sertifikasi } \\
\text { Halal } \\
(X 2)\end{array}$ & $\begin{array}{l}\text { Penjualan } \\
\text { (Y) }\end{array}$ \\
\hline \multirow{3}{*}{$\begin{array}{l}\text { Eksebisi } \\
\text { (X1) }\end{array}$} & Pearson Correlation & 1 & $.699^{* *}$ & $.837^{\star \star}$ \\
\hline & Sig. (2-tailed) & . & .000 & .000 \\
\hline & $\mathrm{N}$ & 55 & 55 & 55 \\
\hline \multirow{3}{*}{$\begin{array}{l}\text { Sertifikasi } \\
\text { Halal (X2) }\end{array}$} & Pearson Correlation & $.699^{* *}$ & 1 & $.826^{* \star}$ \\
\hline & Sig. (2-tailed) & .000 & . & .000 \\
\hline & $\mathrm{N}$ & 55 & 55 & 55 \\
\hline \multirow[t]{3}{*}{ Penjualan $(\mathrm{Y})$} & Pearson Correlation & $.837^{* *}$ & $.826^{* *}$ & 1 \\
\hline & Sig. (2-tailed) & .000 & .000 & . \\
\hline & $\mathrm{N}$ & 55 & 55 & 55 \\
\hline
\end{tabular}

Dari hasil tersebut diatas dapat diketahui pengaruh dari masing-masing variabel sebagai berikut :

a. Hubungan Eksebisi $\left(\mathrm{X}_{1}\right)$ dengan Variabel Penjualan (Y)

Koefisien korelasi parsial Eksebisi $\left(\mathrm{X}_{1}\right)$ dengan variabel Penjualan $(\mathrm{Y})$ sebesar 0,837 bernilai positif, jadi tingkat korelasinya sangat kuat, yang berarti semakin meningkat Eksebisi $\left(\mathrm{X}_{1}\right)$ semakin meningkat Penjualan (Y). Adapun nilai kontribusi pengaruh (koefisien determinasi) sebesar 70,1\% terhadap Penjualan dan sisanya 29,9\% disebabkan oleh faktor-faktor yang lainnya..

b. Hubungan Variabel Sertifikasi Halal $\left(\mathrm{X}_{2}\right)$ dengan Variabel Penjualan $(\mathrm{Y})$

Koefisien korelasi parsial sebesar 0,826 menunjukkan korelasi antara sertifikasi halal $\left(\mathrm{X}_{2}\right)$ dengan variabel Penjualan (Y) bernilai positif dan berkorelasi sangat kuat. Adapun kontribusi pengaruhnya diketahui dari koefisien determinasi sebesar $68,2 \%$ terhadap variabel Penjualan dan sisanya $31,8 \%$ disebabkan oleh faktorfaktor yang lainnya.

c. Hubungan Eksebisi $\left(\mathrm{X}_{1}\right)$ dan Sertifikasi Halal $\left(X_{2}\right)$ secara simultan dengan Penjualan (Y)

Korelasi simultan antara Eksebisi $\left(\mathrm{X}_{1}\right)$ dan Sertifikasi Halal $\left(X_{2}\right)$ dengan Penjualan (Y) melalui model Summary diperoleh nilai $\mathrm{r}$ sebesar 0,903 yang menunjukkan korelasi sangat kuat sedangkan koefisien determinasi sebesar 0,815 menunjukkan kontribusi pengaruh sebesar $81,5 \%$.

\section{Analisis Regresi Linear Berganda}

Hasil analisis regresi linear berganda sebagai berikut : 
Tabel 3

Analisis Regresi Linear Berganda

Coefficients

\begin{tabular}{|c|c|c|c|c|c|c|}
\hline \multirow[b]{2}{*}{ Mod } & & \multicolumn{2}{|c|}{$\begin{array}{c}\text { Unstandardized } \\
\text { Coefficients }\end{array}$} & \multirow{2}{*}{$\begin{array}{c}\begin{array}{c}\text { Standardized } \\
\text { Coefficients }\end{array} \\
\text { Beta }\end{array}$} & \multirow[b]{2}{*}{$t$} & \multirow[b]{2}{*}{ Sig. } \\
\hline & & B & Std. Error & & & \\
\hline \multirow[t]{3}{*}{1} & (Constant) & 10.342 & 1.929 & & 5.363 & .000 \\
\hline & Eksebisi (X1) & .443 & .073 & .508 & 6.094 & .000 \\
\hline & $\begin{array}{l}\text { Sertifikasi } \\
\text { Halal (X2) }\end{array}$ & .448 & .079 & .471 & 5.650 & .000 \\
\hline
\end{tabular}

Berdasarkan tabel di atas dapat ditentukan nilai persamaan regresi linear berganda sebagai berikut: $Y=10,342+$ $0,443 \mathrm{X}_{1}+0,448 \mathrm{X}_{2}$

Persamaan tersebut dapat dijelaskan sebagai berikut :

a. Nilai konstanta sebesar 10,342 menunjukkan bahwa jika Eksebisi $\left(\mathrm{X}_{1}\right)$ dan sertifikasi halal $\left(X_{2}\right)$ meningkat 1 satuan, maka variabel Penjualan $(\mathrm{Y})$ akan meningkat sebesar 10,342.

b. Nilai koefisien regresi Eksebisi $\left(\mathrm{X}_{1}\right)$ sebesar 0,443 menunjukkan jika Eksebisi $\left(X_{1}\right)$ mengalami peningkatan 1 satuan, maka akan meningkatkan variabel Penjualan $(\mathrm{Y})$ sebesar 0,443 , dengan asumsi sertifikasi halal $\left(\mathrm{X}_{2}\right)$ dianggap konstan.

c. Nilai koefisien regresi sertifikasi halal $\left(\mathrm{X}_{2}\right)$ sebesar 0,448, berarti jika sertifikasi halal $\left(X_{2}\right)$ meningkat 1 satuan maka variabel Penjualan $(\mathrm{Y})$ akan meningkat sebesar 0,448 dengan asumsi variabel Eksebisi $\left(\mathrm{X}_{1}\right)$ dianggap konstan.

\section{Uji t}

Berdasarkan hasil uji $\mathrm{t}$ tersebut di atas, bahwa secara signifikan Eksebisi $\left(\mathrm{X}_{1}\right)$ berpengaruh positif terhadap variabel Penjualan $(\mathrm{Y})$ dimana nilai $t_{\text {hitung }}=6.094>$ $t_{\text {tabel }}=1,661$. Begitu juga sertifikasi halal $\left(X_{2}\right)$ terhadap variabel Penjualan $(Y)$, dimana nilai $t_{\text {hitung }}=5.650>t_{\text {tabel }}=1,661$ menunjukkan adanya pengaruh signifikan positif terhadap variabel Penjualan $(\mathrm{Y})$.

\section{Uji F (Anova)}

Hasil uji F (Anova) dapat diketahui pada tabel berikut ini.

\section{Tabel 4}

Uji Anova

\begin{tabular}{|c|c|c|c|c|c|c|}
\hline \multicolumn{2}{|c|}{ Mode } & $\begin{array}{l}\text { Sum of } \\
\text { Squares }\end{array}$ & $d f$ & Mean & $F$ & Sig. \\
\hline \multirow[t]{3}{*}{1} & Regression & 3885.751 & 2 & \multirow{3}{*}{$\begin{array}{r}1942.875 \\
16.982\end{array}$} & \multirow[t]{3}{*}{114.405} & \multirow[t]{3}{*}{$.000^{\circ}$} \\
\hline & Residual & 883.086 & 52 & & & \\
\hline & Total & 4768.836 & 54 & & & \\
\hline
\end{tabular}

Berdasarkan pada hasil uji ANOVA diperoleh $F_{\text {hitung }}=114,405>F_{\text {tabel }}(53)=2,650$ pada tingkat signifikan 0,000 karena 0,000 $<0,05$, maka dapat dikatakan Eksebisi $\left(X_{1}\right)$ dan sertifikasi halal $\left(X_{2}\right)$ secara simultan berpengaruh terhadap variabel Penjualan (Y).

\section{Pembahasan}

Responden penelitian yang berpartisipasi semuanya telah memproduksi produksi bersertifikasi halal dalam beragam produk (barang atau jasa) seperti: Restoran (Restaurant), Minuman dan bahan minuman (Beverages and Beverages Ingredient), Mi, Pasta dan Produk olahannya (Noodles, Pasta and Processed products), Jamu (Herbal), Roti dan Kue (Bakery), Es Krim dan bahan pendukungnya (Ice Cream and Supporting Ingredient, Kosmetik (Cosmetic), Susu dan produk olahannya (Milk and Dairy Products), Tepung, Pati dan produk derivative/olahan (Flour, Starch and Derivative/Processed Product) dan Makanan Ringan (Snack).

Peningkatan permintaan pasar yang ditandai dengan peningkatan omzet penjualan produk halal salah satunya sebagai dampak positif dari kesadaran dan strategi promosi melalui keterlobatan dalam kegiatan pameran produk, termasuk secara khusus pameran produk halal baik pada level daerah, nasional maupun internasional. 
Ditemukannya pengaruh dengan arah positif antara eksebisi terhadap penjualan dalam penelitian, sejalan dengan penelitian sebelumnya yang dilakukan Sonang Sitohang (2008) dimana pameran perdagangan (trade exhibition) secara signifikan mempengaruhi kinerja pemasaran. Emi Supariyani (2004) bahwa biaya promosi melalui pameran yang telah dikeluarkan perusahaan dapat meningkatkan volume penjualan.

Demikian pula penelitian Joko Mei Rianto dan Meizy Heriyanto (2015) dimana ditemukan bahwa pameran berpengaruh secara signifikan terhadap tingkat Penjualan. Demikian pula penelitian Anna Wulandari dan M. Echsanullah (2018) dimana ditemukan bahwa Pameran memiliki pengaruh terhadap Penjualan dengan arah positif, artinya semakin tinggi Pameran maka semakin tinggi pula Penjualan.

Faktor keberadaan produk yang tersertifikasi halal dinilai merupakan nilai jual yang memiliki pengaruh positif dalam peningkatan penjualan produk. Hal tersebut tidak terlepas dari jumlah konsumen di Indonesia yang mayoritas Muslim serta peluang pasar produk halal di mancanegara.

Pengaruh positif produk bersertikasi halal yang ditemukan dalam penelitian ini, sejalan dengan penelitian Salindal (2018), dimana ditemukan bahwa sertifikasi halal secara signifikan mempengaruhi kinerja inovatif perusahaan makanan bersertifikat halal. Selanjutnya, peningkatan kinerja inovatif mengarah pada peningkatan kinerja pasar pada aspek penjualan.

Penelitian ini pun sesuai dengan hasil penelitian dari Karim, et.al (2018) melalui aplikasi structural equation modeling techniques (SEM) menemukan bahwa kepercayaan (trusth) pada produk makanan yang bersertifikat halal berdampak positif pada kinerja (performance) penjualan dari pabrikan makanan halal di Malaysia.

\section{KESIMPULAN}

1. Eksebisi berpengaruh signifikan dalam arah yang positif terhadap penjualan produk halal.

2. Sertifikasi halal berpengaruh signifikan dalam arah yang positif terhadap peningkatan penjualan produk halal.

\section{SARAN}

1. Perusahaan yang menargetkan produk halal sangat penting memperhatikan sertifikasi halal pada produk yang dihasilkan. Disisi lain, keikutsertaan pada kegiatan promosi melalui pameran (eksebisi) terutama pada kegiatan seperti expo produk halal akan lebih meningkatkan peluang pasar dan penguatan networking dalam bisnis.

2. Dalam penelitian terdapat keterbatasan seperti keterlibatan jumlah sampel penelitian yang dilibatkan dari satu kegiatan eksebisi produk halal saja. Diperlukan pengembangan pada penelitian selanjutnya.

\section{DAFTAR PUSTAKA}

Abdul M., Ismail H., Mustapha M., and Kusuma H., Indonesian Small Medium Enterprises (SMEs) and Perceptions on Halal Food Certification, African Journal of Business Management, Vol. 7(16), pp. 1492-1500, 28 April, 2013 DOI: 10.5897/AJBM 11.2926

Awan H.M., Siddiquei A.N. and Haider Z., Factors affecting Halal purchase intention - evidence from Pakistan's Halal food sector, Management Research Review Vol. 38 No. 6, 2015 pp. 640-660, DOI 10.1108/MRR-012014-0022 
Chen, E., Flint, S., Perry, P., Perry, M. and Lau, R., 2015, Implementation of NonRegulatory Food Safety Management Schemes In New Zealand: A Survey of The Food And Beverage Industry, Food Control, Vol. 47, pp. 569-576

Daroin A.D, Joyoatmojo S., Susilaningsih, 2015, Upaya Pengembangan Usaha Mikro Kecil dan Menengah (UMKM) Handycraft Kayu Jati di Dusun Bandar Desa Batokan Kecamatan Kasiman Kabupaten Bojonegoro, Jurnal Pendidikan Ekonomi, Vol. 1, No 2, 2015

Echsanullah M., dan Wulandari A., 2018, Pameran, Personal Selling dan Iklan Media Online dalam Mendorong Penjualan Property, Jurnal Pengembangan Wiraswasta, Vol. 20 No. 03, Desember 2018, hal 171-182

Ismaeel M., Blaim K., Toward applied Islamic Business Ethics: Responsible Halal Business, Journal of Management Development Vol. 31 No. 10, 2012 pp. 1090-1100,

DOI: $10.1108 / 02621711211281889$

Karim, R. A., Nawi, N. M., Razak, N. A., Marmaya, N. H., \& Ridzuan, A. R. Bin. 2018. The Relationship between Food Product with the JAKIM Halal Certification and Performance of Certified Halal Food Manufacturers. International Journal of Academic Research in Business and Social Sciences, 8(10), 629- 639.

Kotler, P., dan Amstrong G, 2014. Alih bahasakan Bob Sabran. Prinsipprinsip Pemasaran, Edisi 13

Li, L-Y. (2008). The effects of firm resources on trade show performance: How do trade show marketing processes matter. Journal of Business \& Industrial Marketing, 23, 35-47.

Lin, C.-T., \& Lin, C. W., 2013, Exhibitor Perspectives of Exhibition Service Quality. Journal of Convention \& Event Tourism, 14(4), 293-308, DOI:10.1080/15470148.2013.837020

Marzuki S.Z.S.,, Hall C.M. and Ballantine P.W., Restaurant Managers' Perspectives on Halal Certification,
Journal of Islamic Marketing Vol. 3 No. 1, 2012 pp. 47-58, DOI $10.1108 / 17590831211206581$

Prabowo S., Rahman A.A, Rahman S.A., Samah A.A., Revealing Factors Hindering Halal Certification in East Kalimantan Indonesia, Journal of Islamic Marketing Vol. 6 No. 2, 2015 pp. 268-291, DOI: 10.1108/JIMA-052014-0040

Rianto, J.M., dan Herriyanto, M., 2015, Publisitas Melalui Pameran Terhadap Tingkat Penjualan Sepeda Motor, Kasus Pada Sepeda Motor Kawasaki PT. Greentech Cakrawala Motorindo Pekanbaru, Jom FISIP, Volume 2 No.1 Februari 2015, Hal 1-10

Salindan N.A, 2018, Halal Certification Compliance and Its Effects On Companies' Innovative and Market Performance, Journal of Islamic Marketing, September 2018, Emerald Publishing Limited, DOI 10.1 108/JIMA04-2018-0080

Sitohang S., Pengaruh Kreativitas Dan Trade Exhibition Terhadap Inovasi Berkelanjutan dan Kinerja Pemasaran Sentra Industri Kecil Mebel Kayu di Kabupaten Madiun, Ekuitas Jurnal Ekonomi dan Keuangan, Vol. 12, No 3, 2008, hal 295-319.

Supariyani, E (2004) Pengaruh Biaya Pelaksanaan Promosi Melalui Pameran Terhadap Tingkat Volume PENJUALAN pada PT. Astra International Tbk-Isuzu Cabang Bogor

Talib M.S.A, Chin T.A., and Fischer J., 2017, Linking Halal food certification and business performance, British Food Journal, I Vol. 119 No. 7, 2017 pp. 1606-1618, DOI 10.1108/BFJ-01-20170019

Wu H.C., Cheng C.C., and Ai C.H. A Study Of Exhibition Service Quality, Perceived Valve, Emotion, Satisfaction, And Behavioral Intentions, Event Management, Vol. 20, pp. 565-591, 2016, DOI: $10.3727 / 152599516 \times 14745497664514$

Website: 
https://www.statista.com/topics/4428/globa l-halal-market/ https://goukm.id/5-manfaat-pameran-bagipromosi-ukm/ 